\title{
Family Support and Self-Esteem of Patient with Breast Cancer
}

Jek Amidos Pardede*, Marthalena Simamora, Galvani Volta Simanjuntak

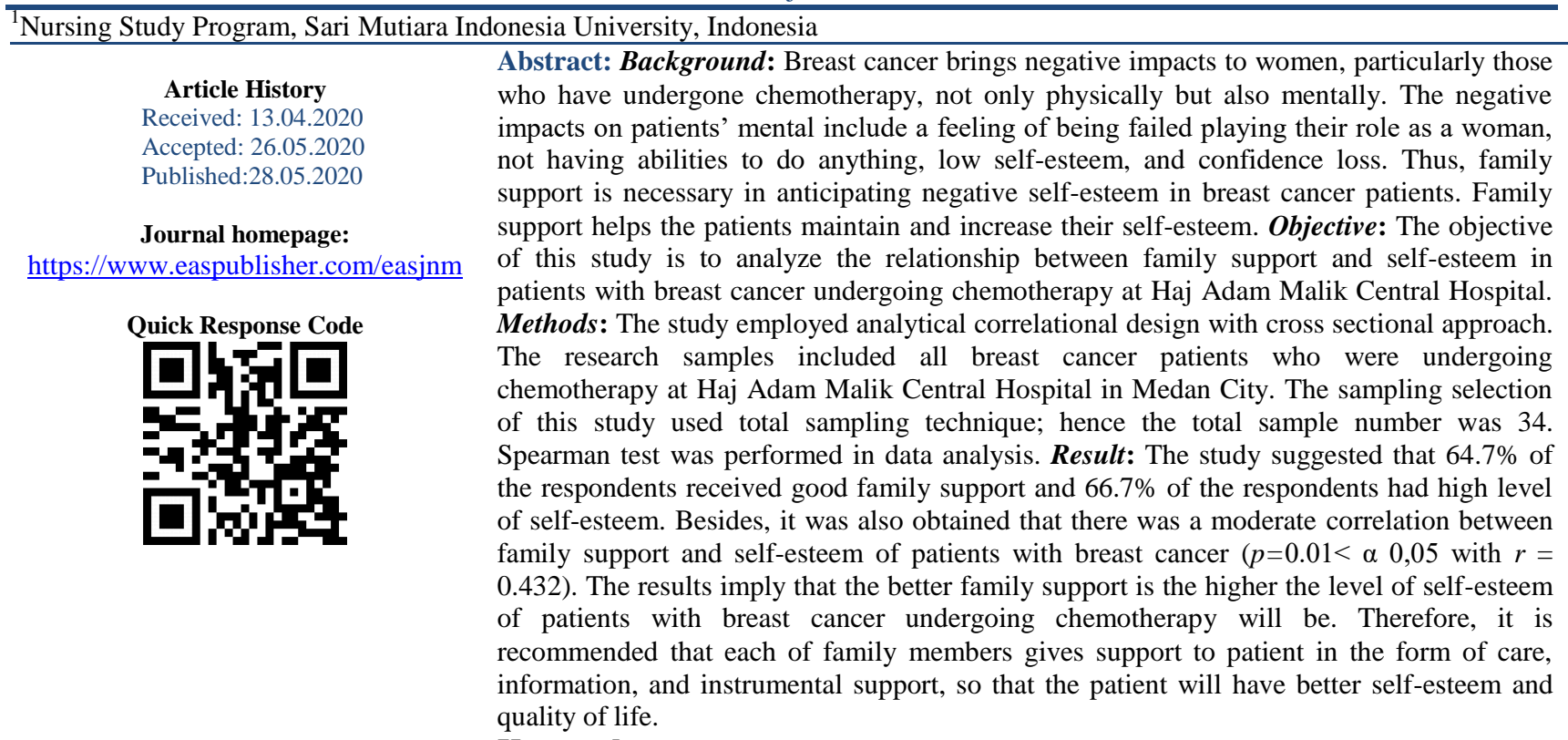

Keywords: Family support, Self-esteem, Breast cancer.

Copyright (C) 2020 The Author(s): This is an open-access article distributed under the terms of the Creative Commons Attribution 4.0 International License (CC BY-NC 4.0) which permits unrestricted use, distribution, and reproduction in any medium for non-commercial use provided the original author and source are credited.

\section{INTRODUCTION}

Breast cancer is a disease caused by uncontrolled growth of breast cells or breast tissues (Taufan, 2011). The risk factors that are associated with breast cancer include reproductive factors, endocrine factors, diet and genetic or family health history (Rasjidi, 2009).

World Health Organization (2013) reported an increasing trend of incidence of breast cancer in countries throughout the world from time to time. In 2012, the number of breast cancer cases among women was 17 million and increased to 21 million cases in 2013. It is suggested that there are nearly 230.000 new breast cancer cases every year in Europe, while 170.000 new cases are found each year in the United States. Based on the estimate of Globocan, International Agency for Research on Cancer (IARC), there will be 18.1 million new cancer cases (17.0 million cases excluding nonmelanoma skin cancer) and 9.6 million death cases caused by cancer (9.5 million cases excluding nonmelanoma skin cancer) in 2018.
Breast cancer has become the most common type of cancer that caused the highest mortality rate among women in Indonesia (Masriadi, 2016). Overall, the prevalence of cancer in Indonesia is 1.4 per 1000 people; meanwhile the province with the highest prevalence of cancer is Yogyakarta with the prevalence is 9.6 per 1000 people. In Medan City, approximately 786 cases of cancer were found in 2014. The result of the preliminary survey conducted by the researchers suggested that there were 458 patients suffering from breast cancer at $\mathrm{H}$. Adam Malik Central Hospital (Medical Record of Haji Adam Malik Central Hospital).

Breast cancer affects human life in various sectors on daily basis. Breasts are not only for breast milk production, but also have aesthetic value for women so that they bring psychological meaning to women (Hawari, 2004). Physical changes caused by the disease, procedures and medical treatment results in psychological problems in breast cancer patients which eventually affects their self-esteem (Kamelia, 2012).

In many cases, patients with breast cancer perceive negatively on themselves leading to negative perceptions on their roles as housewife or wife. On the 
process of undergoing chemotherapy, it is likely that patients grow various kinds of negative feelings and thoughts, such as low self-esteem, anxiety, hopelessness, rejection, and enthusiasm and confidence loss. Therefore, support from family members and society will help the patients undergoing chemotherapy to improve their self-esteem (Listyowati, 2012).

Family plays crucial role in how patients shape their self-esteem. The self-esteem of patients with breast cancer is the reflection of how family members regard the patients and their disease. Each of family members should be able to teach the patients how to accept their health condition and commit to medical treatment procedures for their healing. If family has a holistic and consistent positive self-esteem, it will provide a loving and caring environment to the patient. With family support, it is easier for the patient to carry out their activities and overcome challenges related to the disease. Besides, the feeling of being loved and cared brings positive emotions and helps them deal with their problems (Stuart, 2014). Based on the discussion, it is intriguing for the researchers to analyze the relationship between family support and self-esteem in patients with breast cancer undergoing chemotherapy at Haj Adam Malik Central Hospital in Medan City.

\section{RESEARCH METHOD}

This study was an analytical correlational study using cross sectional approach. The research population was breast cancer patients undergoing chemotherapy at Haj Adam Malik Central Hospital in Medan City. Through total sampling technique, 34 people were selected as research samples. A set of questionnaire were administered to measure the relationship between family support and self-esteem of patients with breast cancer who underwent chemotherapy. The collected data were analyzed using Spearman Rho Test.

\section{RESULTS}

The demographic characteristics of respondents in the study were majorly in the age range between 46-60 years old (47.1\%), married (73.5\%), and senior high school graduates $(55.9 \%)$ (Table 1$)$. It was also obtained that the category of family support toward breast cancer patients undergoing chemotherapy was majorly good, $64.7 \%$ (Table 2), while the level of selfesteem of patients with breast cancer who underwent chemotherapy was high $61.8 \%$ (Table 3 ).

The results of statistical test using spearman correlational calculation obtained that $\mathrm{p}=0.01(\mathrm{p}<0.05)$ and $r=0.432(0.4-0.5$, moderate correlation strength) indicating that there was a significant correlation between family support and self-esteem of breast cancer patients undergoing chemotherapy at Haj Adam Malik Central Hospital. Therefore, it is suggested that the better family support is, the higher the level of self- esteem in breast cancer patients undergoing chemotherapy is.

Table 1. Frequency Distribution of Characteristics of Cancer Patients at Haj Adam Malik Central Hospital

\begin{tabular}{lll}
\hline Characteristics & n & \% \\
\hline Age & & \\
- 30 - 45 years & 10 & 29.4 \\
- 46 - 60 years & 16 & 47.1 \\
- > 60 years & 8 & 23.5 \\
Marital Status & & \\
- Single & 3 & 8.8 \\
- Married & 25 & 73.5 \\
- Divorced/ Widowed & 6 & 17.6 \\
Education & & \\
- Elementary & 2 & 5.9 \\
- Junior High & 8 & 23.5 \\
- Senior High & 19 & 55.9 \\
- Higher Education & 5 & 14.7 \\
Total & 34 & 100 \\
\hline
\end{tabular}

Table 2. Frequency Distribution of Family Support of Breast Cancer Patients at Haj Adam Malik Central Hospital in Medan City

\begin{tabular}{lll}
\hline Family Support & n & \% \\
\hline Good & 22 & 64.7 \\
Bad & 12 & 35.3 \\
\hline
\end{tabular}

Table 3. Frequency Distribution of Self-esteem of Breast Cancer Patients at Haj Adam Malik Central Hospital in Medan City

\begin{tabular}{lll}
\hline Self-esteem & n & \% \\
\hline high & 21 & 61.8 \\
low & 13 & 38.2 \\
\hline
\end{tabular}

Table 4. The Result of Spearman Test on Family Support and Self-esteem of Breast Cancer Patients Undergoing Chemotherapy at Haj Adam Malik Central Hospital in Medan City

\begin{tabular}{|c|c|c|c|c|c|c|}
\hline \multirow{3}{*}{ Family Support } & \multicolumn{3}{|c|}{$\begin{array}{l}\text { Level of } \\
\text { Self-esteem }\end{array}$} & \multirow[t]{2}{*}{ Total } & \multirow{3}{*}{$\mathbf{r}$} & \multirow{3}{*}{$\mathbf{p}$} \\
\hline & High & Lo & & & & \\
\hline & n \% & $\mathbf{n}$ & $\%$ & n $\%$ & & \\
\hline Good & 1750.0 & 5 & 14.7 & 2264.7 & & \\
\hline Bad & $4 \quad 11.8$ & 8 & 23.5 & 1235.3 & 0.43 & 0.012 \\
\hline Total & 2161.8 & 13 & 38.2 & 34100 & & \\
\hline
\end{tabular}

\section{DISCUSSION}

\section{Family Support}

Data in Table 2 shows that the majority of the respondents received good category of family support. Many of the respondents reported that they received advices from their family about their medication. Their family also gave information related to their disease, reminded the patients to undergo chemotherapy and medical check-ups regularly. Besides, their family also accompanied the patients undertaking medication procedures. Family support plays crucial role in the recovery process of ill family member, since it lifts 
patient's motivation and improve health rate (Husni, 2012).

The result of this study is in line with that of Sari, et al. (2012) which found that most of breast cancer patients received good family support (22 patients or $64.7 \%$ ). It can be implied that family support is one of the important aspects in patients who undergo chemotherapy. It is because the support from their family can encourage patients during their chemotherapy process. The patients feel loved and cared despite their poor health condition.

\section{Self-Esteem in Breast Cancer Patients}

The results obtained that the level of selfesteem of patients in this study was majorly high $(61.8 \%)$ (Table 3). The patients reported that they felt worthy, confident, and positive with their situation. Besides, they also reported that they could communicate with their family members and others. The patients also received support, love, and care from their family.

The result of this study according to the result of the result was conducted Leite (2015) about evaluation of self-esteem in cancer patients undergoing chemotherapy treatment, the research found higher frequency of patients with high self-esteem, but some of them showed average or low self-esteem. The scale showed a Cronbach's alpha value of 0.746 , by considering its acceptable internal consistency for the evaluated items. No independent variables showed significant associations with self-esteem. Low selfesteem may occur because there is self-rejection, a feeling of being incapable, shameful, and not worthy. Occasionally, patients find it is difficult to accept their condition, so that it is necessary to teach and motivate patients to be aware of their health status and commit to the medical treatment (Pardede, et al. 2015).

Breast cancer is still one of the most common health issues among women in Indonesia. Woman who is diagnosed to be suffering from breast cancer needs adaptation to her condition. A factor affecting adaptation of a newly diagnosed breast cancer patient is optimism toward healing. This factor is necessary in breast cancer patients because it plays a crucial role in upbringing hope on patient's healing (Wardiyah, 2014).

Cancer is not just a disease that affects the body, it is so terrifying to the extent that it affects a person's confidence in their ability to be in control of their life. (Lee, 2000). Self-esteem is one of the psychological element which may deteriorate when the patient tries to adapt to the problem, deal with their suffering and take control over incidence that has resulted because of the disease. (Leite, 2015).

\section{The Relationship between Family Support and Self- Esteem of Breast Cancer Patients}

Statistical analysis using Spearman correlational calculation obtained that $p$ value $=0.01$ $(\mathrm{P}<0.05)$ with $\mathrm{r}=0,432$ indicating that there was a significant correlation between family support and selfesteem in breast cancer patients undergoing chemotherapy at Haj Adam Malik Central Hospital in Medan City in the year of 2017. The results suggested that the correlation strength was moderate $(0.4-0.5)$

The correlation and positive contribution found in the study was because most of the respondents received good family support and had high self-esteem. It was found that $22(64.7 \%)$ out of 34 respondents undergoing chemotherapy received positive support from their family, and $17(50.0 \%)$ out of 34 respondents had high level of self-esteem. Only 5 respondents $(14.7 \%)$ had low self-esteem. In addition, from the total of 12 respondents with bad family support, 4 respondents were suggested to have high self-esteem $(11.8 \%)$ and 8 respondents had low self-esteem $(23.5 \%)$.

Family support is an important factor in breast cancer patients. and our results showed that higher family support was associated with seft esteem. A prospective study following the patients for 23 years also reported that higher family support was related to lower levels of depression at baseline and quicker improvement of depression. (Kamen, 2011)

Family support is a vital factor for people who are facing problems. The support they receive may encourage them to commit to medication procedures such as chemotherapy. Family support plays a crucial role in improving patient's mental state and spirit which eventually improve their self-esteem (Sari et al., 2012).

Patients with breast cancer may find various alternations in their life. The changes may occur not only on their physic but also on mental condition which affecting their self-esteem. Self-esteem is the result of individual judgment or evaluation toward oneself leading to self-worth. In many cases, breast cancer patients undergoing chemotherapy perceive themselves as weak individuals, imperfect, hopeless, unattractive, not worthy, being isolated and rejected from the society, fearful, hopeless, anxious, and depressed. Moreover, breast cancer patients who are undergoing chemotherapy also experiences psychological impacts caused by their health condition, such as fear of death, of being burden to others, of being abandoned by their family, and self-concept disorders (Rahmadiliyani, 2014).

Generally, social support from patients' close people such as friends and health personnel brings optimism to patients that affect their self-motivation to gain healing. Family support is crucial in anticipating 
psychological problems in breast cancer patients (Wardiyah, 2014). Emotional supports which include positive emotional expressions, empathy, and care toward the patients may lead them to feel better and attain their spirit back despite their poor health condition (Permatasari, 2016). Adequate support from the family is proven to be associated with lower mortality in cancer patients, high healing rate, better condition of cognitive functions and emotion health. Positive and motivating support from family helps improve ones' self-esteem, so that they are more confident facing challenges caused by their disease (Purwanti, 2013).

\section{Conclusions}

1. The Category of family support in breast cancer patients undergoing chemotherapy at Haj Adam Malik Central Hospital in Medan City was good.

2. The category of self-esteem in breast cancer patients undergoing chemotherapy at Haj Adam Malik Central Hospital in Medan City was high.

3. There was a significantly moderate correlation between family support and self-esteem of breast cancer patients undergoing chemotherapy at Haj Adam Malik Central Hospital in Medan.

\section{RECOMMENDATIONS To Patients}

It is suggested that breast cancer patients undergoing chemotherapy to remain motivated and commit to medication procedures and believe in themselves that they will be healed.

\section{To Nurses}

It is suggested that nurses improve their care services to patients particularly in giving psychological supports and approach as well as encouraging the patients to anticipate low self-esteem in cancer patients. It is because low self-esteem in cancer patients may negatively affect their healing process.

\section{To further researcher}

It is suggested that further researcher study about factors affecting family support and self-esteem in patients with breast cancer who undergo chemotherapy.

\section{REFERENCES}

1. Bernard, W. (2014). Stewart and Christopher P. Wild.: World cancer report, ISBN 978-92-8320429-9

2. Ferlay, J., Bray, F., Steliarova-Foucher, E., \& Forman, D. (2010). GLOBOCAN 2008, Cancer Incidence and Mortality Worldwide. IARC CancerBase No. 10. Lyon, France: International Agency for Research on Cancer
3. Hawari, D. (2004). Kanker payudara dimensi psikoreligi. Balai Jakarta, Penerbit FKUI.

4. Husni, M. (2012). Hubungan Dukungan Keluarga Dengan Kualitas Hidup Pasien Kanker Payudara Di Instalasi Rawat Inap Bedah Rsup Dr. Mohammad Hoesin Palembang Tahun , 2(2).

5. Kamelia. (2012). Konsep Diri pada Wanita Penderita Kanker Payudara (Carcinoma Mammae). Skripsi-Program Studi Psikologi Fakultas Dakwah Institut Agama Islam Negeri Sunan Ampel Surabaya.

6. Kamen, C., Cosgrove, V., McKellar, J., Cronkite, R., \& Moos, R. (2011). Family support and depressive symptoms: a 23-year follow-up. Journal of clinical psychology, 67(3), 215-223.

7. Listyowati, R, Wuryanto, E. \& Widodo, S. (2012). Gambaran konsep diri penderita kanker payudara yang dilakukan kemoterapi di rumah sakit dr. Kariadi semarang. 11(1).

8. Lee, H.J., \& Sohn, S.K. (2000). Predictive factors of hope in patients with cancer. $J$ Korean Acad Adult Nurs; 12(2), 184-95

9. Leite, M. A. C., Nogueira, D. A., \& Terra, F. D. S. (2015). Evaluation of self-esteem in cancer patients undergoing chemotherapy treatment. Revista latino-americana de enfermagem, 23(6), 10821089.

10. Masriadi, (2016). Epidemiologi Penyakit Tidak Menular. Jakarta: CV. Trans Info Media.

11. Pardede, J. A., Keliat, B. A., \& Yulia, I. (2015). Kepatuhan dan Komitmen Klien Skizofrenia Meningkat Setelah Diberikan Acceptance And Commitment Therapy dan Pendidikan Kesehatan Kepatuhan Minum Obat. Jurnal Keperawatan Indonesia, 18(3), 157-166.

12. Permatasari, I. I., \& Lestari, S. (2016). Dukungan suami pada istri dalam menjalani pengobatan Pasca Operasi kanker Payudara (Doctoral dissertation, Universitas Muhammadiyah Surakarta).

13. Purwanti, A. (2013). Hubungan Dukungan Keluarga dengan Harga Diri pada Pasien Kanker Payudara di RSUD Panembahan Senopati (Doctoral dissertation, STIKES'Aisyiyah Yogyakarta).

14. Rahmadiliyani, N. (2014). Gambaran Tingkat Pengetahuan Dan Sikap Ibu Tentang Deteksi Dini Kanker Payudara Di Yayasan Kanker Indonesia Cabang Kalimantan Selatan. Jurkessia 5(3). Diperoleh 2 Juli 2017.

15. Rasjidi, I. (2009). Deteksi Dini Kanker Payudara. Jakarta: CV. Sagung Seto. 
16. Sari, M., Dewi, Y. I., \& Utami, A. (2012). Hubungan dukungan keluarga terhadap motivasi pasien kanker payudara dalam menjalani Kemoterapi di Ruang Cendrawasih I RSUD Arifin Achmad Provinsi Riau. Jurnal Ners Indonesia, 2(2), 158-166.

17. Stuart, G. W. (2014). Principles and practice of psychiatric nursing-e-book. Elsevier Health Sciences.
18. Taufan, N. (2011). Asi dan Tumor Payudara, nuha Medika.

19. Wardiyah, A., Afiyanti, Y., \& Budiati, T. (2015). Faktor yang mempengaruhi optimisme kesembuhan pada pasien kanker payudara. Jurnal Keperawatan, 5(2), 121-127.

20. WHO. (2013). Breast Cancer. Atlanta: American Cancer Society. 